\title{
(6) OPEN ACCESS \\ De novo mtDNA point mutations are common and have a low recurrence risk
}

\author{
Suzanne C E H Sallevelt, ${ }^{1}$ Christine E M de Die-Smulders, ${ }^{1,2}$ \\ Alexandra T M Hendrickx, ${ }^{1}$ Debby M E I Hellebrekers, ${ }^{1}$ Irenaeus F M de Coo, ${ }^{3}$ \\ Charlotte L Alston, ${ }^{4}$ Charlotte Knowles, ${ }^{4}$ Robert W Taylor, ${ }^{4}$ Robert McFarland, ${ }_{1}^{4}$ \\ Hubert J M Smeets ${ }^{1,2,5}$
}

- Additional material is published online only. To view please visit the journal online (http://dx.doi.org/10.1136/ jmedgenet-2016-103876).

${ }^{1}$ Department of Clinical Genetics, Maastricht University Medical Centre (MUMC), Maastricht, The Netherlands ${ }^{2}$ Research School for Developmental Biology (GROW), Maastricht University, Maastricht, The Netherlands ${ }^{3}$ Department of Neurology, Erasmus MC-Sophia Children's Hospital Rotterdam,

Rotterdam, The Netherlands ${ }^{4}$ Wellcome Trust Centre for Mitochondrial Research, Institute of Neuroscience, The Medical School, Newcastle University, Newcastle upon Tyne, UK

${ }^{5}$ Research School for Cardiovascular Diseases in Maastricht, CARIM, Maastricht University, Maastricht, The Netherlands

\section{Correspondence to} Suzanne C E H Sallevelt, Department of Clinical Genetics, Maastricht University Medical Centre (MUMC), P. Debeyelaan 25, P.O. Box 5800, Maastricht 6202 AZ, The Netherlands;

suzanne.sallevelt@mumc.nl

Received 1 March 2016 Revised 2 June 2016 Accepted 9 June 2016 Published Online First 22 July 2016

\section{ABSTRACT}

Background Severe, disease-causing germline mitochondrial (mt)DNA mutations are maternally inherited or arise de novo. Strategies to prevent transmission are generally available, but depend on recurrence risks, ranging from high/unpredictable for many familial mtDNA point mutations to very low for sporadic, large-scale single mtDNA deletions. Comprehensive data are lacking for de novo mtDNA point mutations, often leading to misconceptions and incorrect counselling regarding recurrence risk and reproductive options. We aim to study the relevance and recurrence risk of apparently de novo mtDNA point mutations.

Methods Systematic study of prenatal diagnosis (PND) and recurrence of mtDNA point mutations in families with de novo cases, including new and published data. 'De novo' based on the absence of the mutation in multiple (postmitotic) maternal tissues is preferred, but mutations absent in maternal blood only were also included.

Results In our series of 105 index patients (33 children and 72 adults) with (likely) pathogenic mtDNA point mutations, the de novo frequency was $24.6 \%$, the majority being paediatric. PND was performed in subsequent pregnancies of mothers of four de novo cases. A fifth mother opted for preimplantation genetic diagnosis because of a coexisting Mendelian genetic disorder. The mtDNA mutation was absent in all four prenatal samples and all 11 oocytes/embryos tested. A literature survey revealed 137 de novo cases, but PND was only performed for 9 (including 1 unpublished) mothers. In one, recurrence occurred in two subsequent pregnancies, presumably due to germline mosaicism. Conclusions De novo mtDNA point mutations are a common cause of mtDNA disease. Recurrence risk is low. This is relevant for genetic counselling, particularly for reproductive options. PND can be offered for reassurance.

\section{INTRODUCTION}

Mitochondrial diseases due to defective oxidative phosphorylation are the most common inborn errors of metabolism, ${ }^{1}$ with between $15 \%$ and $25 \%$ of cases caused by pathogenic mitochondrial (mt) DNA mutations. ${ }^{12}$ In the majority of cases, these mtDNA mutations are heteroplasmic, a mixture of mutated and wild-type mtDNA molecules in cells and/or tissues of an individual. At a certain level of mtDNA mutant load, the cell expresses dysfunction and symptoms will occur, the so-called threshold effect. This threshold varies within tissues and between different mutations and is difficult to specify for most mtDNA mutations. Nevertheless, mutant loads of below $\sim 18 \%$ are not considered to cause symptoms in $>95 \%$ of the cases. ${ }^{3}$ Severity of clinical involvement broadly increases with a higher heteroplasmy level, although clearly this is not the only factor. Individuals exclusively receive their mtDNA from their mother. It is transmitted, at least in part, through a genetic bottleneck induced by a drastic reduction in the number of mtDNA molecules per primordial germ cell during oogenesis, leaving a few mtDNAs to become the founders for the offspring, although the exact nature and timing of events remain topic of debate. ${ }^{4-8}$ The result is, however, indisputable: children of a woman carrying a heteroplasmic mtDNA mutation can display a wide variety of mutation loads.

Disease-causing mtDNA mutations can be point mutations or single, large-scale deletions/rearrangements as a primary cause, or multiple deletions and depletions usually secondary to a nuclear gene defect or environmental factor (eg, nucleoside RT inhibitors and ageing). The recurrence risk in a subsequent pregnancy depends on the underlying primary genetic defect. The potential of a severe phenotype and the lack of effective treatment often prompts couples who have affected offspring or a positive family history of mtDNA disease to request intervention to prevent transmission.

Women harbouring an mtDNA deletion have a low risk ( 1 in 24$)$ of clinically affected offspring, ${ }^{9}$ whereas females with an mtDNA point mutation potentially have a high risk of recurrence. Often, for female carriers the risk of having an affected child is difficult to predict. However, a substantial proportion of the children with a single, large-scale mtDNA deletion or point mutation have a de novo mutation not inherited from their mother. ${ }^{1}$ The recurrence risk of de novo, single large-scale mtDNA deletions in subsequent offspring is low. ${ }^{9-11}$ For de novo point mutations, one would expect the recurrence risk to be similarly low, although this has not been systematically investigated to date.

In reproductive counselling of mtDNA mutations, the choice between prenatal diagnosis (PND) and preimplantation genetic diagnosis (PGD) depends mainly on the recurrence risk and on the expected predictive value of the test. The latter can be problematic in PND given the potential de Die-Smulders CEM Hendrickx ATM, et al. J Med Genet 2017:54:114-124. 
difficulties of interpreting results for most mtDNA mutations when fetal mutant load falls within a 'grey zone' where correlation between genotype and phenotype is unclear. However, when the likelihood of offspring with either no mutation or a mutant load below the heteroplasmic threshold of disease expression is high, PND can be applied for reassurance. This is the case for single, large-scale mtDNA deletions ${ }^{9-12}$ and for low-level mtDNA mutations demonstrating skewing to the extremes (eg, m.8993T $>\mathrm{G}$ ) in the mother. ${ }^{13}$ Also, when maternal mutation load of a non-skewing mtDNA mutation is very low, PND could be considered. For familial mtDNA mutations showing an unpredictable and/or high recurrence risk, PGD is an attractive option, ${ }^{3}{ }^{14}$ although patient preference and choice plays an important role in the decision-making process. Moreover, other factors including maternal age or pre-existent fertility problems may influence an informed decision regarding preferred reproductive options.

In order to study the relevance and recurrence risk of apparently de novo mtDNA point mutations, we evaluated the occurrence of de novo mtDNA point mutations in our own experience and in the literature, and present data on five couples presenting to our own clinical services who have had an affected child and for whom PND or PGD has been performed in a subsequent pregnancy. We offer recommendations for reproductive counselling including strategies to prevent the birth of children affected by mtDNA disease.

\section{MATERIALS AND METHODS}

Patients and patient data

The frequency of de novo versus recurrent mtDNA disease was studied by cataloguing all (likely) pathogenic mtDNA point mutations identified in our diagnostic laboratory either by specifically screening for known mutations (m.3243A $>\mathrm{G}$, $\mathrm{m} .8344 \mathrm{~A}>\mathrm{G}, \mathrm{m} .8993 \mathrm{~T}>\mathrm{C} / \mathrm{G}$ ) or sequencing the entire mitochondrial genome. 'Likely' pathogenic refers to novel mutations that are suspected to be pathogenic based on well-established prediction tools and accepted criteria; ${ }^{15}{ }^{16}$ however, this was not in all cases proven by functional (eg, single-fibre segregation, transmitochondrial cybrid) studies. In addition, we documented whether maternal relatives of the index patients were tested to determine presence and, if applicable, heteroplasmy levels of the mtDNA mutation. Apparent de novo mtDNA mutations were defined by their absence in one or more accessible maternal tissues (eg, blood, urinary sediment, buccal epithelia) and, if tested, absence in other matrilineal relatives. Conversely, if the mtDNA mutation was detected in the mother and/or other maternal relatives, it was classified as maternally inherited/familial. The de novo frequency was calculated by taking the proportion of apparently de novo mutations from all mtDNA mutations identified between January 1996 and March 2015. Cases where it was not clear whether the reported mtDNA mutation was (apparently) de novo or maternally inherited/ familial because additional familial testing was not possible were excluded from the analysis.

\section{Literature search}

PubMed was systematically searched as of December 2015 for cases of de novo mtDNA mutations. Search terms were 'mtDNA de novo mutation'. PubMed's automated query translation, incorporating $\mathrm{MeSH}$ terms and enhancements from the Unified Medical Language System (UMLS), was as follows: "dna, mitochondrial"[MeSH Terms] OR ("dna"[All Fields] AND "mitochondrial"[All Fields]) OR "mitochondrial dna"[All Fields] OR “mtdna"[All Fields]) AND "de novo"[All Fields] AND
("mutation"[MeSH Terms] OR "mutation"[All Fields]. Also 'related citations' of de novo reports in PubMed were screened.

\section{Prenatal diagnosis and preimplantation genetic diagnosis}

Chorionic villus sampling (CVS) samples were obtained at 10 +4 weeks and $11+2$ weeks gestation, respectively, amniotic fluid sampling at $16+2$ weeks and $16+6$ weeks, respectively. DNA extraction from prenatal and postnatal tissues, quantitative analyses of the mtDNA mutations as well as the PGD procedure were performed as previously described. ${ }^{14} 1617$ Primers used for the Maastricht cases are for m.8993T>C/G: CACACC TACACCCCTTATCCC (forward) and TCATTATGTGTTGTC GTGCAG (reverse); for m.5556G>A: CACCATCATAGCCAC CATCA (forward) and GGCTGAGTGAAGCATTGGAC (reverse); for m.8969G >A: GCTTCATTCATTGCCCCCAC (forward) and AGGGCTATTGGTTGAATGAGTAAG (reverse); and for m.3243A>G: CAACTTAGTATTATACCCACAC (forward) and TTTCGTTCGGTAAGCATTAG (reverse). Mutation-specific restriction enzymes are HpaII (Roche) for m.8993T>C/G, Ddel (Roche) for m.5556G $>$ A, AluI (Roche) for m.8969G $>$ A and HaeIII (Roche) for m.3243A>G. For the Newcastle cases (ref. 18 and unpublished data), pyrosequencing was used to quantitatively assess mtDNA mutation heteroplasmy levels as described previously $^{19}$ (primer sequences available on request). For one patient, further assessment of mtDNA heteroplasmy was undertaken using next-generation sequencing (NGS)-based mtDNA sequencing; briefly, patient DNA samples were amplified by long-range PCR, sheared using the Ion Xpress Plus Fragment Library Kit and sequenced on an Ion Torrent PGM platform according to manufacturer's protocols (Life Technologies, Foster City, California, USA).

\section{RESULTS}

\section{De novo mtDNA point mutations}

In our diagnostic laboratory, 105 index cases were identified based on laboratory diagnoses with a (likely) pathogenic mtDNA point mutation (table 1 and online supplementary table S1). The majority (72/105) being adults, our cohort seems a fair representation of the patient population. A subset of 17 patients were found to harbour an apparently de novo mtDNA mutation (table 1), of which 12 were between 0 and 3 years of age at investigation, whereas 5 were $>18$ years old. Of note, in 3 of 17 cases only maternal blood was analysed, and with a semiquantitative method. In two other mothers, besides blood only hair, and hair plus fibroblasts, respectively, were tested. These cases have a lower probability of being truly de novo than the remaining 12 where besides blood also maternal urine and/or muscle has been investigated. Maternal inheritance was firmly established for 52 patients, 35 of whom were adults (see online supplementary table S1). Notably, for one of these cases (patient 44) we were able to demonstrate de novo occurrence of the pathogenic mtDNA mutation in the mother of the patient, which might also be the case for two other families (families 14 and 20). For the outstanding 36 patients, it remains unknown whether the mtDNA mutation arose de novo in the index patient or not (see online supplementary table S1). Accordingly, $17 / 69(24.6 \%)$ of the (likely) pathogenic mtDNA point mutations occurred de novo in the index patient in our series. Additionally, we identified a further 137 de novo cases in the literature (see online supplementary table S2; those published from our own centre and therefore shown in table 1 or online supplementary table S1 are not included). These are listed according to whether the mother and/or siblings were tested as well, and if so, whether this was carried out in one or more tissues to assess mtDNA heteroplasmy levels. Reports with 
Table 1 (Likely) Pathogenic mtDNA mutations identified in our diagnostic laboratory (Maastricht), presumably de novo in the index patients

\begin{tabular}{|c|c|c|c|c|c|c|c|}
\hline & Reference & $\begin{array}{l}\text { Family } \\
\text { no. }\end{array}$ & Gene & Mutation & $\begin{array}{l}\text { Mutation load(s) in tested tissue(s) } \\
\text { of index patient }\end{array}$ & $\begin{array}{l}\text { Mutation load(s) in tested tissues } \\
\text { of (maternal) relative(s) }\end{array}$ & $\begin{array}{l}\text { Index patient's age at } \\
\text { investigation }\end{array}$ \\
\hline \multicolumn{8}{|c|}{ De novo cases } \\
\hline 1. & - & 16390 & MTTL1 & m.3243A>G & $12 \%(\mathrm{BI})$ & $\begin{array}{l}\text { Mother: } \mathrm{n}(\mathrm{Bl}, \mathrm{U}) \\
\text { Daughter: } 4 \%(\mathrm{U})\end{array}$ & 44 \\
\hline 2. & - & 19462 & MTTL1 & $\mathrm{m} .3243 \mathrm{~A}>\mathrm{G}$ & $8 \%(\mathrm{M}, \mathrm{BI})$ & Mother: $\mathrm{n}(\mathrm{Bl}, \mathrm{U})$ & 3 \\
\hline 3. & $\begin{array}{l}\text { This article } \\
\text { (case 5) }\end{array}$ & 22023 & MTTL1 & m. $3243 A>G$ & $\begin{array}{l}13 \%(\mathrm{BI}), 12 \%(\mathrm{M}), 17 \%(\mathrm{~F}), 16 \%(\mathrm{U}), \\
14 \%(\mathrm{BM})\end{array}$ & $\begin{array}{l}\text { Mother: } n(B I, M, B M) \\
11 \text { oocytes/embryos in PGD cycle: }\end{array}$ & 2 \\
\hline 4. & $\begin{array}{l}\text { This article } \\
\text { (case 2) }\end{array}$ & 15503 & MTTW & m.5556G $>A$ & $\begin{array}{l}>90 \%(\mathrm{M}) \text { (not tested in our } \\
\text { laboratory) }\end{array}$ & $\begin{array}{l}\mathrm{n} \text { Mother: } \mathrm{n}(\mathrm{Bl}, \mathrm{H}, \mathrm{U}, \mathrm{M}) \\
\text { Mother's subsequent pregnancy: } \\
\mathrm{n} \text { (amniocentesis) }\end{array}$ & 0 \\
\hline 5. & $\begin{array}{l}\text { This article } \\
\text { (case 3) }\end{array}$ & 17063 & MTATP6 & $\mathrm{m} .8969 \mathrm{G}>\mathrm{A}$ & $95 \%(B I, F, M)$ & $\begin{array}{l}\text { Mother: } \mathrm{n}(\mathrm{Bl}, \mathrm{U}) \\
\text { Mother's subsequent pregnancy: } \\
\mathrm{n} \text { (amniocentesis) }\end{array}$ & 0 \\
\hline 6. & $\begin{array}{l}\text { This article } \\
\text { (case 1) }\end{array}$ & 7387 & MTATP6 & $\mathrm{m} .8993 \mathrm{~T}>\mathrm{G}$ & $90 \%(\mathrm{M})$ & $\begin{array}{l}\text { Mother: } \mathrm{n}(\mathrm{Bl}, \mathrm{H}, \mathrm{M}) \\
\text { Mother's subsequent pregnancy: } \\
\mathrm{n}(\mathrm{CVS})\end{array}$ & 1 \\
\hline 7. & $\begin{array}{l}\text { This article } \\
\text { (case 4) }\end{array}$ & 19006 & MTATP6 & $\mathrm{m} .8993 \mathrm{~T}>\mathrm{G}$ & $97 \%(\mathrm{Bl}, \mathrm{M}), 96 \%(\mathrm{~F})$ & $\begin{array}{l}\text { Mother: } \mathrm{n}(\mathrm{Bl}, \mathrm{U}, \mathrm{H}) \\
\text { Mother's subsequent pregnancy: } \\
\mathrm{n} \text { (abortus material) } \\
\text { Mother's second subsequent } \\
\text { pregnancy: } \mathrm{n} \text { (CVS) }\end{array}$ & 0 \\
\hline 8. & - & 21838 & MTATP6 & $\mathrm{m} .8993 \mathrm{~T}>\mathrm{G}$ & $92 \%(\mathrm{M}), 90 \%(\mathrm{BI})$ & Mother: $n(B I, U)$ & 1 \\
\hline 9. & - & 14652 & MTATP6 & m. $9155 A>G$ & $88 \%(M)$ & Mother: $\mathrm{n}(\mathrm{Bl}, \mathrm{M})$ & 1 \\
\hline 10. & - & 9868 & MTND3 & m.10191T $>C$ & $100 \%(B I, M)$ & Mother: $\mathrm{n}(\mathrm{BI}, \mathrm{M}, \mathrm{H}, \mathrm{U})$ & 0 \\
\hline 11. & - & 2869 & MTTS2 & m. $12207 \mathrm{G}>\mathrm{A}$ & $\begin{array}{l}>60 \%(\mathrm{M}), \mathrm{n}(\mathrm{BI}) \text { (with } \\
\text { semiquantitative sequence analysis) }\end{array}$ & $\begin{array}{l}\text { Mother: } \mathrm{n}(\mathrm{BI}) \text { (with semiquantitative } \\
\text { sequence analysis) }\end{array}$ & 41 \\
\hline 12. & Blok et $a l^{49}$ & 6604 & MTND5 & $\mathrm{m} .13511 \mathrm{~A}>\mathrm{T}$ & $65 \%(\mathrm{BI}), 53-65 \%(\mathrm{~F}), 72 \%(\mathrm{M})$ & Mother: $\mathrm{n}(\mathrm{M}, \mathrm{BI}, \mathrm{H})$ & 3 \\
\hline 13. & Blok et $a /^{49}$ & 2339 & MTND5 & m.13513G >A & $4-6 \%(\mathrm{Bl}), 13-15 \%(\mathrm{M}), 1-5 \%(\mathrm{~F})$ & $\begin{array}{l}\text { Mother: } \mathrm{n}(\mathrm{Bl}, \mathrm{F}, \mathrm{H}) \\
\text { Two sisters: } \mathrm{n}(\mathrm{BI}) \\
\text { Maternal grandmother: } \mathrm{n}(\mathrm{BI}, \mathrm{F})\end{array}$ & 19 \\
\hline 14. & Blok et $a l^{49}$ & 4707 & MTND5 & m.13513G >A & $11-16 \%(B \mathrm{I}), 17 \%(\mathrm{H}), 16 \%(\mathrm{M}), \mathrm{n}(\mathrm{F})$ & $\begin{array}{l}\text { Mother: } n(B I, H) \\
\text { Maternal grandmother: } n(B I, H)\end{array}$ & 1 \\
\hline 15. & - & 18686 & MTND5 & m.13513G >A & $1 \%(\mathrm{BI}), 10 \%(\mathrm{M})$ & Mother: $\mathrm{n}(\mathrm{Bl}, \mathrm{M})$ & 42 \\
\hline 16. & - & 22006 & MTCYB & m.15153G >A & $\begin{array}{l}\text { Heteroplasmic (BI, M) (with } \\
\text { semiquantitative sequence analysis) }\end{array}$ & $\begin{array}{l}\text { Mother: } \mathrm{n}(\mathrm{BI}) \text { (with semiquantitative } \\
\text { sequence analysis) }\end{array}$ & 43 \\
\hline 17. & - & 27171 & MTCYB & m.15158A>G & $\begin{array}{l}\text { Heteroplasmic (BI, M) (with } \\
\text { semiquantitative sequence analysis) }\end{array}$ & $\begin{array}{l}\text { Mother: } n \text { (BI) (with semiquantitative } \\
\text { sequence analysis) }\end{array}$ & 0 \\
\hline
\end{tabular}

Mutations are listed according to nucleotide position.

BI, blood; BM, buccal mucosa; CVS, chorionic villus sampling; F, fibroblasts; $H$, hair; $M$, muscle; $n$, normal (mutation not detected); PGD, preimplantation genetic diagnosis; $U$, urine.

apparently de novo mtDNA mutations where no (close/relevant) relatives were tested ${ }^{20-24}$ are not included in the table.

\section{PND/PGD in subsequent pregnancies}

The parents of four of the five children described below with apparently de novo mtDNA disease (figure 1, tables 1 and 2) were counselled in the outpatient department of Clinical Genetics in Maastricht. For case 3, the parents were counselled at another centre while mtDNA analyses were performed in Maastricht.

\section{Case 1}

Couple 1 was referred for PGD because their son had Leigh syndrome due to the m.8993T $>\mathrm{G}$ mutation in the MTATP6 gene, with $90 \%$ mutant load in skeletal muscle. He died at the age of 1 . Family history was otherwise negative. His healthy older sister, 6 years of age, was not tested for the mutation. In the mother's blood, hair and muscle the m.8993T $>\mathrm{G}$ mutation was absent (detection level $<1 \%$ ). The mutation seeming to have arisen de novo in their son, a low recurrence risk was estimated and PND was offered for reassurance. The couple were surprised because maternal inheritance of the m.8993T $>\mathrm{G}$ mutation was assumed, based on the high mutation percentage and severe disease in the affected child, and they were counselled as having a high recurrence risk. Furthermore, they were informed that PND was not an option because of limitations in predicting the phenotype of the offspring and PGD was recommended. The couple opted for PND. The mutation was not detected in chorionic villus DNA and a healthy daughter was born. The child has not been genetically tested post partum, but is still doing well at the age of 11 .

\section{Case 2}

Couple 2 was referred for PGD. Their daughter had a mitochondrial disorder due to oxidative phosphorylation defects (strongly diminished complex I, III and IV activities). She was shown to carry an m.5556G $>$ A mutation in the MTTW gene, with $>90 \%$ heteroplasmy level in skeletal muscle. This mutation had not been described before. Pathogenicity was based on the disruption of the tertiary structure of mt-tRNA ${ }^{\operatorname{Trp}}$ by the mutation, and the compatibility of the mutation with the combined deficiency of complexes I, III and IV, which was also demonstrated in transmitochondrial cybrids. ${ }^{25}$ She died when she was 1.5 years old. Family history was negative. The mother's blood, 


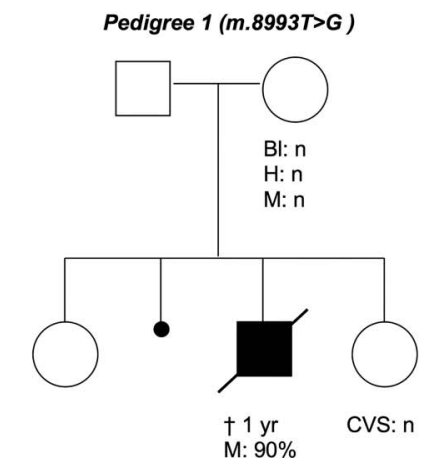

Pedigree 3 (m.8969G $>$ A )

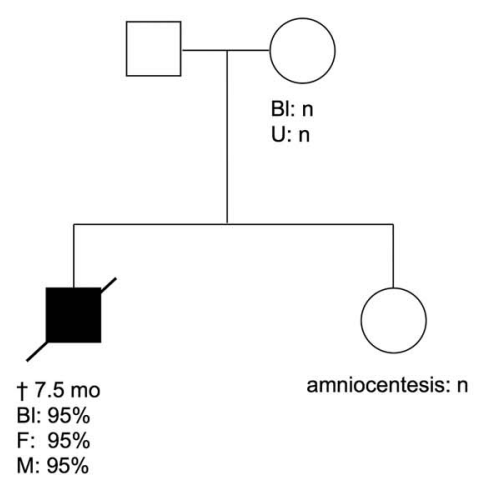

Pedigree 2 (m.5556G>A)

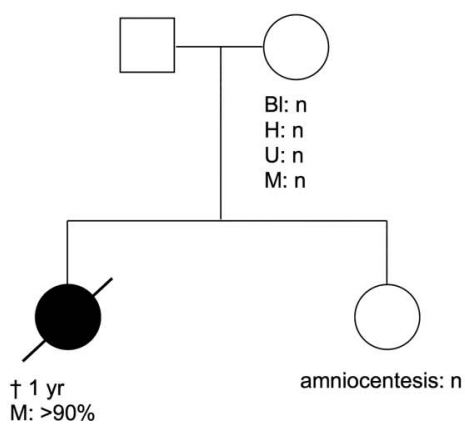

Pedigree $4(m .8993 T>G)$

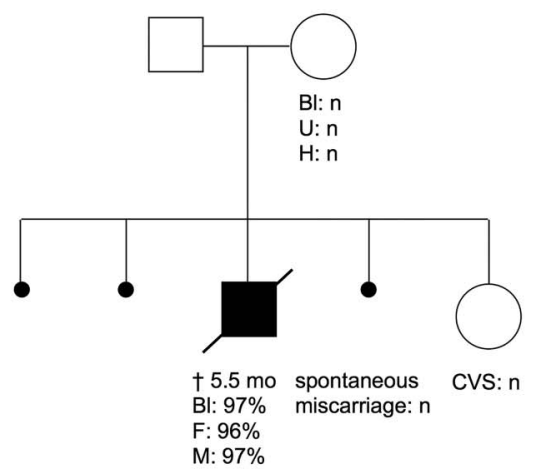

Pedigree 5 ( $m .3243 A>G)$
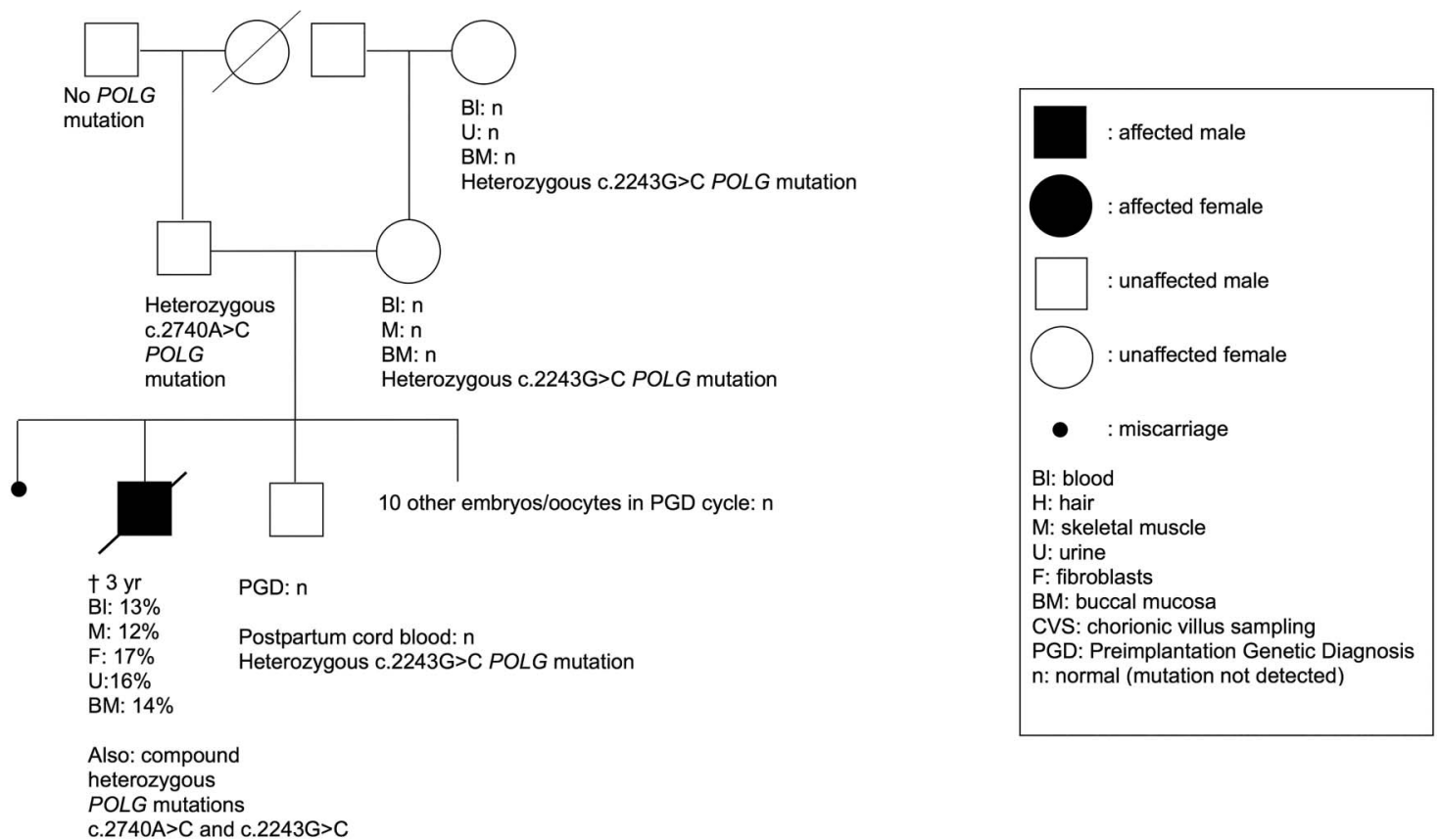

Figure 1 Pedigrees of the five case descriptions in this report.

hair, urine and muscle did not show the m.5556G $>$ A mutation (detection level $<1 \%$ ), and accordingly, the mutation was considered de novo in their daughter, further supporting a pathogenic role. The recurrence risk was regarded as low and PND was offered. PGD seemed a less suitable option because of the presumed low recurrence risk and the maternal age (38 years). As in case 1 , the couple was surprised since at the referring centre PND was not considered an option because of uncertainties about the representativeness of the prenatal sample for the fetus, about the stability of the mutant load over time, and about the clinical phenotype to be expected. Amniocentesis revealed no mutation. A healthy daughter was born, who is now 4 years old. No mutation analysis was performed post partum. 
Table 2 Presumably de novo mtDNA mutations for which prenatal diagnosis (PND) and/or preimplantation genetic diagnosis (PGD) has been performed in a subsequent pregnancy (Maastricht+Newcastle+literature)

\begin{tabular}{|c|c|c|c|c|c|}
\hline & Reference & Gene & Mutation & $\begin{array}{l}\text { Mutation load(s) in tested tissue } \\
\text { (s) of index patient }\end{array}$ & Mutation load(s) in tested tissues of (maternal) relative(s) \\
\hline 1. & This article (case 1 ) & MTATP6 & $\mathrm{m} .8993 \mathrm{~T}>\mathrm{G}$ & $90 \%(\mathrm{M})$ & $\begin{array}{l}\text { Mother: } \mathrm{n}(\mathrm{Bl}, \mathrm{H}, \mathrm{M}) \\
\text { Mother's subsequent pregnancy: } \mathrm{n} \text { (CVS) }\end{array}$ \\
\hline 2. & This article (case 2 ) & MTTW & m.5556G $>A$ & $>90 \%(\mathrm{M})$ & $\begin{array}{l}\text { Mother: } n(B I, H, U, M) \\
\text { Mother's subsequent pregnancy: } n \text { (amniocentesis) }\end{array}$ \\
\hline 3. & This article (case 3 ) & MTATP6 & $\mathrm{m} .8969 \mathrm{G}>\mathrm{A}$ & $95 \%(B I, F, M)$ & $\begin{array}{l}\text { Mother: } \mathrm{n}(\mathrm{Bl}, \mathrm{U}) \\
\text { Mother's subsequent pregnancy: } \mathrm{n} \text { (amniocentesis) }\end{array}$ \\
\hline 4. & This article (case 4) & MTATP6 & $\mathrm{m} .8993 \mathrm{~T}>\mathrm{G}$ & $97 \%(\mathrm{Bl}, \mathrm{M}), 96 \%(\mathrm{~F})$ & $\begin{array}{l}\text { Mother: } \mathrm{n}(\mathrm{BI}, \mathrm{U}, \mathrm{H}) \\
\text { Mother's subsequent pregnancy: } \mathrm{n} \text { (abortus material) } \\
\text { Mother's second subsequent pregnancy: } \mathrm{n} \text { (CVS) }\end{array}$ \\
\hline 5. & This article (case 5) & MTTL1 & m.3243A $>\mathrm{G}$ & $\begin{array}{l}13 \%(\mathrm{BI}), 12 \%(\mathrm{M}), 17 \%(\mathrm{~F}) \\
16 \%(\mathrm{U}), 14 \%(\mathrm{BM})\end{array}$ & $\begin{array}{l}\text { Mother: } n \text { (BI, M, BM) } \\
11 \text { oocytes/embryos in PGD cycle: } n\end{array}$ \\
\hline 6. & Lebon et $a^{\beta 7}$ & MTND3 & m.10158T>C & $85 \%(\mathrm{M})$ & $\begin{array}{l}\text { Mother: } \mathrm{n} \text { (BI) } \\
\text { Mother's subsequent pregnancy: } \mathrm{n} \text { (CVS and amniocentesis) }\end{array}$ \\
\hline 7. & Steffann et $\left.a\right|^{38}$ & MTATP6 & $\mathrm{m} .8993 \mathrm{~T}>\mathrm{G}$ & $90 \%(\mathrm{Bl})$ & $\begin{array}{l}\text { Mother: } \mathrm{n}(\mathrm{BI}) \\
\text { Mother's subsequent pregnancy: } \mathrm{n} \text { (CVS and amniocentesis) } \\
\text { Mother's second subsequent pregnancy: } \mathrm{n} \text { (amniocentesis) }\end{array}$ \\
\hline 8. & Shanske et $a l^{\beta 9}$ & MTND5 & $\mathrm{m} .13513 \mathrm{G}>\mathrm{A}$ & $89 \%(M), 80 \%(B I)$ & $\begin{array}{l}\text { Mother: } \mathrm{n}(\mathrm{BI}, \mathrm{U}) \\
\text { Mother's subsequent pregnancy: } \mathrm{n} \text { (amniocentesis) } \\
\text { Postpartum analysis of this sister: } \mathrm{n} \text { (cord blood, } \mathrm{BI}) \\
\text { Maternal aunt: } \mathrm{n}(\mathrm{BI}, \mathrm{U}) \\
\text { Maternal grandmother: } \mathrm{n}(\mathrm{Bl}, \mathrm{U})\end{array}$ \\
\hline 9. & Marchington et $a l^{34}$ & MTATP6 & m.9176T>C & $\begin{array}{l}99 \% \text { (in 'all tissues examined', } \\
\text { not further specified) }\end{array}$ & $\begin{array}{l}\text { Mother: } n \text { (BI, BM, } \mathrm{U}, 15 \text { oocytes), } 40 \% \text { ( } 2 \text { oocytes together; could } \\
\text { not be dissected separately), } \leq 5 \% \text { (1 oocyte) } \\
\text { Mother's subsequent pregnancy: } n \text { (CVS) } \\
\text { Postpartum analysis of this sibling: } n \text { (16 samples of placenta, } \\
\text { cord blood) }\end{array}$ \\
\hline 10. & Götz et al ${ }^{40}$ & MTTS1 & m.7453G $>A$ & $100 \%(\mathrm{M})$ & $\begin{array}{l}\text { Mother: } n \text { (BI) } \\
\text { Mother's subsequent pregnancy: } n \text { (CVS) }\end{array}$ \\
\hline 11. & Shanske et $a l^{41}$ & MTND3 & $\mathrm{m} .10198 \mathrm{C}>\mathrm{T}$ & $100 \%(\mathrm{M}$, heart, liver, brain) & $\begin{array}{l}\text { Mother: } n \text { (BI, } U, H \text { ) } \\
\text { Mother's subsequent pregnancy: } n \text { (CVS and amniocentesis, also: } \\
\text { prenatal fetal muscle biopsy) } \\
\text { Postpartum analysis of this sister: } n \text { (placenta portion, } \\
\text { cord blood, H) } \\
\text { Maternal grandmother: } n \text { (U) }\end{array}$ \\
\hline 12. & $\begin{array}{l}\text { Nesbitt et al, }{ }_{1}^{18} \text { personal } \\
\text { communication }\end{array}$ & MTATP6 & m.9176T >C & $97 \%(B I, M)$ & $\begin{array}{l}\text { Mother: } n \text { (BI, U) } \\
\text { Mother's subsequent pregnancy: } 98 \% \text { (CVS) } \\
6 \text { embryos in PGD cycle: } n \text { (no pregnancy achieved) } \\
\text { Mother's second (spontaneous) subsequent pregnancy: } 8 \% \text { (CVS) }\end{array}$ \\
\hline 13. & $\begin{array}{l}\text { Nesbitt et al, }{ }_{1}^{18} \text { personal } \\
\text { communication }\end{array}$ & MTND6 & m.14453G $>A$ & $65 \%(M), 39 \%(F)$ & $\begin{array}{l}\text { Mother: } n(M, B I, U, B M) \\
\text { Mother's subsequent pregnancy: } n \text { (CVS) }\end{array}$ \\
\hline 14. & $\begin{array}{l}\text { Unpublished data from } \\
\text { Newcastle }\end{array}$ & MTND5 & m.13513G $>A$ & $81 \%(M)$ & $\begin{array}{l}\text { Mother: } n \text { (BI) } \\
\text { Mother's subsequent pregnancy: } n \text { (CVS) }\end{array}$ \\
\hline
\end{tabular}

Bl, blood; BM, buccal mucosa; CVS, chorionic villus sampling; F, fibroblasts; $H$, hair; $M$, muscle; $n$, normal (mutation not detected); U, urine.

Case 3

The son of couple 3 died at age 7.5 months carrying the m.8969G >A mutation in the MTATP6 gene with 95\% heteroplasmy in blood, fibroblasts and skeletal muscle. The m.8969G > A mutation was not detected in the mother's blood and urine (detection level $<1 \%$ ). The couple opted for PND in a subsequent pregnancy, and amniocentesis showed no mutation. A healthy girl was born, now almost 4 years old. She has not been tested for the mutation post partum.

\section{Case 4}

Couple 4 was referred to discuss their reproductive options because their son had Leigh syndrome caused by an almost homoplasmic m.8993T $>\mathrm{G}$ mutation in the MTATP6 gene, demonstrated in his blood, fibroblasts and skeletal muscle. He died when he was 5.5 months of age. In the mother's blood, urine and hair, the m.8993T $>\mathrm{G}$ mutation was not present (detection level $<1 \%$ ). The mutation therefore appeared de novo in their son, resulting in a low recurrence risk. The boy also had neurofibromatosis type 1 (NF1) caused by a de novo mutation c. 2155 dupA in the NF1 gene. Since recurrence risks of both the m.8993T $>\mathrm{G}$ and the NF1 mutation were low, PND was offered. The subsequent pregnancy ended in a spontaneous miscarriage. The m.8993T $>\mathrm{G}$ mutation was not detected in the abortus. Subsequently, a further spontaneous pregnancy was achieved. CVS was performed and the m.8993T $>\mathrm{G}$ was not detected in chorionic villi. A healthy daughter was born, who is presently 2 years old. No mutation analysis was performed post partum.

\section{Case 5}

Couple 5 was referred to us to discuss the possibility of PGD because their son harboured the m.3243A>G MTTL1 mutation. Mutation loads were $13 \%, 12 \%, 17 \%, 16 \%$ and $14 \%$ in his blood, skeletal muscle, fibroblasts, urine and buccal mucosa cells, respectively. The mutation was absent in the mother's 
blood, muscle and buccal mucosa (detection level $<1 \%$ ); the mutation was also absent in the maternal grandmother's blood, urine and buccal mucosa, consistent with a de novo mutation in the index patient and a low recurrence risk of m.3243A>G-related disease. It was doubtful, however, whether the boy's severe, infantile-onset, clinical presentation with hypotonia, feeding problems, psychomotor retardation and intractable epilepsy could be explained by the relatively low mutation load of the m.3243A $>\mathrm{G}$ mutation, and just prior to his death at age 3, compound heterozygosity for the POLG mutations c.2740A >C, p.(Thr914Pro) and c.2243G >C, p.(Trp748Ser) was diagnosed, which was consistent with his clinical features of Alpers' syndrome. Both parents were carriers (father c.2740A $>$ C, p.(Thr914Pro) and mother c.2243G $>$ C, p.(Trp748Ser)), resulting in a recurrence risk of $25 \%$ for the recessive POLG mutations. The couple preferred PGD to PND. Despite the presumed low recurrence risk for the m.3243A $>\mathrm{G}$ mutation, they also requested analysis of the embryos for the m.3243A $>\mathrm{G}$ mutation. It was agreed that of the embryos one blastomere was tested for $P O L G$ and one blastomere for m.3243A $>$ G. Since testing for the m.3243A $>$ G mutation was performed as reassurance, analysis of one blastomere seemed reasonable, although two blastomeres are usually analysed. ${ }^{14} \mathrm{In}$ none of the 11 embryos and oocytes the m.3243A > G mutation was detected. One embryo, heterozygous for one of the POLG mutations, was transferred and resulted in a successful pregnancy. The couple did not opt for PND to confirm the PGD result. A healthy son was born. Postpartum DNA analysis was performed in cord blood and confirmed the blastomere genotype and absence of the m.3243A>G mutation.

In the literature, together with one unpublished case from Newcastle, we identified a further 11 prenatal diagnoses, performed in 9 pregnant mothers of a previously identified case of de novo mtDNA disease. These are listed in table 2, together with our own five cases. All but one case (case 12) showed normal prenatal results. One of the mothers (also case 12) additionally underwent one PGD treatment.

\section{DISCUSSION}

Irrespective of the mechanism leading to mtDNA disease in a child, parents may desire to prevent disease in a subsequent child. The reproductive options available to such couples largely depend on the genetic aetiology. Based on data provided from our own clinical experience and from cases published in the literature, we conclude that mtDNA mutations arise de novo in a significant number of cases and that the recurrence risk for apparently de novo mtDNA mutations is low.

A common approach to determine whether an mtDNA mutation occurred de novo is by testing multiple tissues from the mother for the heteroplasmic mtDNA variant. It is, however, remarkable that often only the mother's blood is analysed even when the mutation was not tested or detected in the affected child's blood (see online supplementary table S2). It is well known, at least for certain mtDNA mutations, ${ }^{26-28}$ that mutant load in blood, a rapidly dividing tissue, can decrease over time due to negative selection. This clearly has implications for the reliability of maternal blood in evaluating de novo occurrence of an mtDNA mutation. Therefore, preferably muscle (a postmitotic tissue) should be included in the maternal analysis, which has however the drawback of an invasive procedure. Notably, needle muscle biopsy sampling nowadays offers a less invasive, more rapid alternative to conventional open muscle biopsies, yielding a sufficient muscle amount for DNA analysis. Urine epithelium has been shown to be a reliable non-invasive alternative for the m.3243A>G mutation. ${ }^{29}$ This may also be true for other pathogenic mtDNA point mutations, ${ }^{30}$ although urine mutant load has not been compared with muscle levels for these. Evaluation of tissue distribution is also critical in light of potential selection events in the germline. Negative selection has been suggested for pathogenic tRNA mutations with low blood mutant levels (pointing to detrimental effects in replicating cells), which are less likely to be transmitted and as a consequence occur more often in isolated cases. ${ }^{31}$ Similarly, negative germline selection has been proposed for deleterious heteroplasmic mtDNA mutations and for de novo mutations in a recent study of healthy humans. ${ }^{32}$ These findings implicate that mutations that are absent or (very) low level in the index patient's blood may be more likely to have indeed occurred de novo. This cannot, however, be assumed for individual mutations without careful analysis of the mother. Furthermore, conversely, potential positive selection events in the germline whereby high mutation loads in offspring could result from low maternal levels cannot be excluded and again stress the importance of thorough maternal investigation. In addition to analysis of maternal tissues, testing apparently healthy siblings of the affected child can contribute to the likelihood that a mutation occurred de novo. The method used to assess mtDNA heteroplasmy is of critical importance. Fluorescent last-cycle restriction fragment length polymorphism (RFLP) analysis has a detection level of $<1 \%$, whereas Sanger sequencing has a sensitivity of between $5 \%$ and $30 \%$ to detect different heteroplasmic mutations (unpublished laboratory findings). Even using lastfluorescent RFLP analysis, the absence of a mutation in the mother is obviously not definitive as a mutation load below the detection threshold for the assay in the mother cannot be excluded, neither can the presence of the mutation in her untested tissues, particularly oocytes.

\section{Proportion of mtDNA point mutations arising de novo in patients with mtDNA disease}

Based on the absence of the mtDNA mutation in (mostly multiple) maternal tissue(s), $24.6 \%$ of the putative pathogenic mtDNA point mutations in our cohort were de novo, a significant subset of cases. which is in agreement with available data from other centres (see online supplementary table S2). ${ }^{1}$ Since paediatric patients seem over-represented in the de novo subgroup, whereas the majority of the entire cohort are adult patients, the proportion of de novo mutations is likely higher in the paediatric patient population and lower in adults.

De novo mtDNA point mutations manifesting below the threshold required for phenotypic expression are clearly not included in this number. It is, however, important to realise that de novo mutations in asymptomatic individuals could potentially segregate to high levels and thus cause mtDNA diseases in subsequent generations. This mechanism is also illustrated by our cases (grey-coloured cases in online supplementary tables S1 and S2) where a mutation did not occur de novo in the index patient, but in the healthy mother (or another maternal relative). Such carriers with low mtDNA mutation loads themselves will only be identified if they have a clinically affected child.

\section{Recurrence risk of de novo mtDNA mutation or disease}

The recurrence risk of a de novo mtDNA mutation depends on the moment at which the mutation arose. A germline de novo mutation event, which reaches clinical significance, most likely occurs at the lowest point of the bottleneck during oogenesis, when the mtDNA copy number is lowest. The same de novo event is not expected to happen twice and the recurrence risk is 
therefore negligible. Mutations may also be pre-existent in (some) maternal oocytes, representing gonadal mosaicism and resulting in a potential recurrence risk. Oocyte sampling has been used to further estimate the recurrence risks of mtDNA mutations, ${ }^{33} 34$ although the invasive nature of this procedure may pose ethical questions if no assisted fertility treatment is intended. Also, it is still not guaranteed that the analysed oocytes are representative of the entire oocyte pool. Finally, a de novo mutation may represent a de novo somatic mutation (being by definition not present in the mother) rather than a de novo germline mutation. In the latter scenario, there is no risk of recurrence. Somatic mutations may be present in only one tissue (eg, skeletal muscle); however, also when detected in several tissues, even of different embryonic origin (such as muscle and urinary epithelial cells, ${ }^{35}$ or muscle and hair roots, ${ }^{36}$ respectively), the mtDNA mutation can be somatic, having occurred very early in embryological development. Taken together, it is nigh impossible to distinguish whether an mtDNA mutation occurred de novo somatically or in the germline (and if so, at what point in the germline) in single-disease cases. In practice, all three scenarios should be considered in cases of apparently de novo mtDNA mutations and as such are taken together in empirically established recurrence risks as discussed below.

Our PND/PGD data of subsequent pregnancies obtained from five mothers of patients with de novo mtDNA disease indicate a very low recurrence risk for de novo mtDNA mutations. These results are supported by (un)published data in which PND in subsequent pregnancies following affected children with an apparently de novo mtDNA mutation were reported in nine mothers (table $2^{18} 34^{37-41}$ ). In eight of these, the mtDNA mutation was not detected in the prenatal sample(s). The absence of the mtDNA mutation in 97 siblings of individuals with a presumed de novo mtDNA mutation further adds to the low recurrence risk of these mutations (table 1 and online supplementary table S2). However, in most asymptomatic siblings of an index patient (a low) mtDNA mutation load could not be excluded as they were not tested for the mutation on ethical grounds. Recurrence risk is increased in the case of gonadal mosaicism, which was shown for one of the de novo cases in the literature (case 9, table $2 /$ case 58 , online supplementary table $\mathrm{S} 2{ }^{34}$ ). The single case where the mutation was present in subsequent pregnancies of the mother (case 12, table 2/case 59, online supplementary table $\mathrm{S}^{18}$ ) without being detectable in her blood or urine is presumably also an example of gonadal mosaicism. The maternal mutation analysis was repeated using deep NGS analysis, but even with this the mtDNA mutation could not be detected in the mother. It is the only case known so far where three offspring have the same mtDNA mutation that is not detectable in the mother. The pattern of distribution of mutation load in this mother's offspring with very high levels in some (her affected child and one of the prenatal samples), but no mutation in the majority (six embryos), is quite similar to an m.8993T $>$ G carrier with low mutant load we previously described (case 44, online supplementary table $\mathrm{S} 1^{14}$ ). Interestingly, the two cases of (presumed) maternal gonadal mosaicism in table 2 concern the same mtDNA mutation, m.9176T $>$ C. ${ }^{1834}$

The total number of prenatal/preimplantation samples described in this paper is 50 , including multiple pregnancies per female (cases 7 and 12, table 2) multiple oocytes and/or embryos per female (cases 5, 9 and 12, table 2) and analysed abortus material (case 4, table 2). In four of these samples, the mtDNA mutation present in the index patient was detected, indicating a recurrence risk of $8 \%(4 / 50)$. Larger numbers of (normal) prenatal diagnoses are presently not available to include in our analysis. However, we do have results in siblings that can be added. Also, 100 siblings of 57 individuals with an apparently de novo mtDNA mutation based on absence of the mutation in the mother (note: families where the mother of such an individual was not analysed, cases 79 and 80 in online supplementary table S2, were not included in this calculation) were tested, both from our own centre and from the literature. In one of these, the mtDNA mutation might be present at low levels in a clinically unaffected sibling (case 108, online supplementary table $\mathrm{S} 2^{36}$ ), although recurrence is debatable here since the sibling's mutation load is at the limit of detection. Besides, in the mother only blood was tested, which is also the case in a second recurrence example (case 97, online supplementary table $\mathrm{S} 2{ }^{42}$ ). In a third case, the mutation was present ( $3 \%$ mutant load) in the sibling's urine, whereas it was absent in the mother's blood and urine (case 122, online supplementary table $S 2^{43}$ ). Considering both the prenatal/preimplantation data $(n=50)$ and the sibling data $(n=100)$, a recurrence risk of approximately $4 \%$ is calculated $(5-7 / 150)$ in this data set. It is likely that this percentage further decreases when all healthy siblings that were not tested could be included.

Few other reports from family studies potentially describe recurrence, but the data are not unambiguous. These include a case where the similarly affected sibling was not tested for the mtDNA mutation and pathogenicity of the mutation has not been proven (case 93, online supplementary table S2 ${ }^{44}$ ); and two cases where relatives with neurological symptoms were not extensively or not at all tested for the mtDNA mutation, whereby it remained unclear whether these symptoms are related to the familial mtDNA mutation or represent a separate disease (cases 50 and 79, online supplementary table S2 ${ }^{45}$ ). Presence of the m.14484T $>C$ mutation in an unaffected sibling, when no mutation was detectable in the mother, was reported in a monozygotic twin (case 136, online supplementary table $\mathrm{S}^{47}$ ), consistent with no recurrence.

Even if all the cases discussed (with the exception of the monozygotic twin) would actually represent recurrence despite absence of the mutation in the mother, 8 examples in 154 cases (17 from our own centre, 137 from literature) would still support our hypothesis of a low recurrence risk, considering the likely bias that exceptional cases may be more easily reported. Furthermore, it is important to note that in none of the (potential) recurrence cases (including the proven gonadal mosaicism one) postmitotic tissue such as muscle was analysed in the mother. None of these involved the m.3243A $>\mathrm{G}$ mutation.

\section{Reproductive counselling strategy for mtDNA disease}

When a couple with a child affected by mtDNA disease seeks counselling regarding the likelihood of having subsequent unaffected offspring, an individual risk assessment should be performed, leading to personalised advice (figure 2). The first step is to ascertain the genetic cause of the disease. As is illustrated by case 5 , finding a pathogenic mtDNA mutation does not always provide an unequivocal answer and the mtDNA heteroplasmy level and clinical phenotype should be consistent with previous reports of affected individuals. If a causative mtDNA mutation is identified, the next step is to evaluate whether the mutation occurred de novo or was maternally inherited. It is necessary to examine multiple tissues in the mother preferably including a postmitotic tissue such as muscle if possible (needle-biopsy suffices) and being mindful of the tissues anticipated to harbour the mutation at detectable levels. For the m.3243A $>\mathrm{G}$ mutation, urine can be considered a 


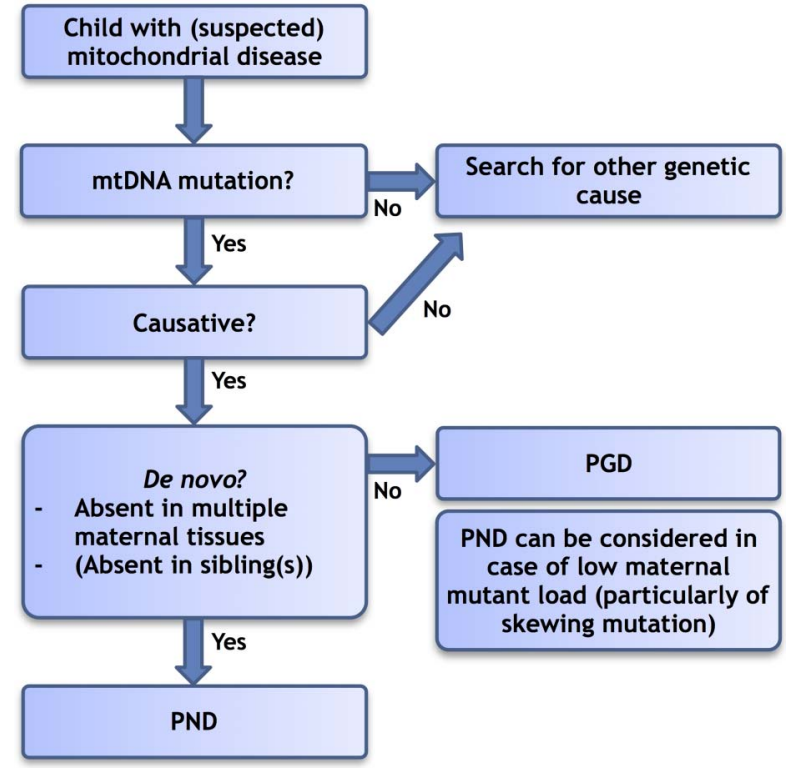

Figure 2 Flow chart: simplified reproductive counselling strategy for mitochondrial (mt)DNA disease. Patient's preferences have not been explicitly included in this algorithm; however, they obviously are an important factor as well. Choices are made on a case-by-case basis. PGD, preimplantation genetic diagnosis; PND, prenatal diagnosis.

reliable alternative for muscle, but for other mutations this correlation has not been validated. A quantitative method with low detection level $(<1-2 \%)$, such as fluorescent RFLP, pyrosequencing or NGS, should be used. Testing of unaffected siblings of the affected child should be considered but may be deemed unacceptable on ethical grounds. As it will be impossible to fully exclude a mutation in the mother, partly due to technical reasons and the availability of tissues or oocytes (note: oocyte sampling might be considered), couples should be aware of a small residual risk. Based on our current calculation, this risk may be $\sim 4 \%$, although the actual risk is likely to be lower. If a couple wishes reproductive genetic testing, PND is the preferred option given the high likelihood that the mutation will not be present in the fetus. PND is also a fair option for carriers with low mutation load (eg, <10\%) of familial mutations, particularly for an mtDNA mutation that manifests skewed segregation, and for single, large-scale mtDNA deletions, the latter both for healthy mothers of an affected child and for affected women themselves. Although amniocentesis seems to be the preferred method for some mtDNA mutations, ${ }^{48}$ one can discuss the relevance of this in situations where no mutation is to be expected at all. CVS, on the other hand, has the advantage that results can be obtained earlier in the pregnancy. In most familial mtDNA mutations, with a high or unpredictable recurrence risk in offspring, and given the potential difficulties of interpreting PND results, PGD is currently the best reproductive option. ${ }^{14}$ Decisions on reproductive options naturally also depend on personal considerations of the individual couple; providing all the available options and information is the key to being able to make a well-informed decision.

Acknowledgements The authors thank the families who have been included in this report.

Contributors SCEHS collected the data (from own diagnostic services and from literature), wrote the article. CEMdD-S counselled the four described patients, supervised writing the article (including reviewing and editing). ATMH, DMEIH, CK and CLA undertook the genetic laboratory (research) work, reviewed and edited the article. IFMdC counselled/referred the fifth described patient (case 3) and reviewed the article. RWT, head of NHS Highly Specialised Mitochondrial Diagnostic Laboratory in Newcastle upon Tyne, supervised the Newcastle laboratory work, reviewed and edited the article. RM, clinical lead of the Newcastle paediatric mitochondrial disease service, reviewed and edited the article. HJMS, head of research group Mitochondrial Genetics at Maastricht University, supervised the Maastricht laboratory work and supervised writing the article (including reviewing and editing).

Funding RWT and RM are supported by The Wellcome Trust Centre for Mitochondrial Research (096919Z/11/Z), the Medical Research Council (UK) Centre for Translational Muscle Disease Research (G0601943), The Lily Foundation and the UK NHS Highly Specialised Commissioners which funds the 'Rare Mitochondrial Disorders of Adults and Children' Diagnostic Service in Newcastle upon Tyne (http:// www.newcastle-mitochondria.com). CLA is the recipient of a National Institute for Health Research (NIHR) doctoral fellowship (NIHRHCS-D12-03-04).

Disclaimer The views expressed are those of the authors and not necessarily those of the NHS, the NIHR or the Department of Health.

Competing interests None declared.

Patient consent Obtained.

Ethics approval Local ethics committee.

Provenance and peer review Not commissioned; externally peer reviewed.

Data sharing statement Technical appendix (primer sequences) available upon request.

Open Access This is an Open Access article distributed in accordance with the terms of the Creative Commons Attribution (CC BY 4.0) license, which permits others to distribute, remix, adapt and build upon this work, for commercial use, provided the original work is properly cited. See: http://creativecommons.org/licenses/ by/4.0/

\section{REFERENCES}

1 Thorburn DR. Mitochondrial disorders: prevalence, myths and advances. J Inherit Metab Dis 2004;27:349-62.

2 Rötig A, Munnich A. Genetic features of mitochondrial respiratory chain disorders. J Am Soc Nephrol 2003;14:2995-3007.

3 Hellebrekers DM, Wolfe R, Hendrickx AT, de Coo IF, de Die CE, Geraedts JP, Chinnery PF, Smeets HJ. PGD and heteroplasmic mitochondrial DNA point mutations: a systematic review estimating the chance of healthy offspring. Hum Reprod Update 2012;18:341-9.

4 Cree LM, Samuels DC, de Sousa Lopes SC, Rajasimha HK, Wonnapinij P, Mann JR, Dahl HH, Chinnery PF. A reduction of mitochondrial DNA molecules during embryogenesis explains the rapid segregation of genotypes. Nat Genet 2008;40:249-54.

5 Khrapko K. Two ways to make an mtDNA bottleneck. Nat Genet 2008;40:134-5.

6 Wai T, Teoli D, Shoubridge EA. The mitochondrial DNA genetic bottleneck results from replication of a subpopulation of genomes. Nat Genet 2008;40:1484-8.

7 Cao L, Shitara H, Sugimoto M, Hayashi J, Abe K, Yonekawa H. New evidence confirms that the mitochondrial bottleneck is generated without reduction of mitochondrial DNA content in early primordial germ cells of mice. PLoS Genet 2009;5:e1000756.

8 Samuels DC, Wonnapinij P, Cree LM, Chinnery PF. Reassessing evidence for a postnatal mitochondrial genetic bottleneck. Nat Genet 2010;42:471-2; author reply $472-3$

9 Chinnery PF, DiMauro $S$, Shanske $S$, Schon EA, Zeviani M, Mariotti C, Carrara F, Lombes $A$, Laforet $P$, Ogier $H$, Jaksch $M$, Lochmuller $H$, Horvath $R$, Deschauer $M$, Thorburn DR, Bindoff LA, Poulton J, Taylor RW, Matthews JN, Turnbull DM. Risk of developing a mitochondrial DNA deletion disorder. Lancet 2004;364:592-6.

10 Zeviani M, Antozzi C. Mitochondrial disorders. Mol Hum Reprod 1997;3:133-48.

11 Chinnery PF, Hudson G. Mitochondrial genetics. Br Med Bull 2013;106:135-59.

12 DiMauro S, Hirano M. Mitochondrial DNA deletion syndromes. In: Pagon RA, Adam MP, Ardinger HH, Wallace SE, Amemiya A, Bean LJH, Bird TD, Fong CT, Mefford HC, Smith RJH, Stephens K, eds. GeneReviews(R). Seattle, WA: University of Washington, Seattle, 1993.

13 White SL, Collins VR, Wolfe R, Cleary MA, Shanske S, DiMauro S, Dahl HH, Thorburn DR. Genetic counseling and prenatal diagnosis for the mitochondrial DNA mutations at nucleotide 8993. Am J Hum Genet 1999:65:474-82.

14 Sallevelt SC, Dreesen JC, Drüsedau M, Spierts S, Coonen E, van Tienen FH, van Golde RJ, de Coo IF, Geraedts JP, de Die-Smulders CE, Smeets HJ. Preimplantation genetic diagnosis in mitochondrial DNA disorders: challenge and success. J Med Genet 2013;50:125-32.

15 McFarland R, Elson JL, Taylor RW, Howell N, Turnbull DM. Assigning pathogenicity to mitochondrial tRNA mutations: when "definitely maybe" is not good enough. Trends Genet 2004;20:591-6.

16 Richards S, Aziz N, Bale S, Bick D, Das S, Gastier-Foster J, Grody WW, Hegde M, Lyon E, Spector E, Voelkerding K, Rehm HL. Standards and guidelines for the interpretation of sequence variants: a joint consensus recommendation of the 
American College of Medical Genetics and Genomics and the Association for Molecular Pathology. Genet Med 2015;17:405-24.

17 Jacobs LJ, de Coo IF, Nijland JG, Galjaard RJ, Los FJ, Schoonderwoerd K, Niermeijer MF, Geraedts JP, Scholte HR, Smeets HJ. Transmission and prenatal diagnosis of the T9176C mitochondrial DNA mutation. Mol Hum Reprod 2005;11:223-8.

18 Nesbitt V, Alston CL, Blakely EL, Fratter C, Feeney CL, Poulton J, Brown GK, Turnbull DM, Taylor RW, McFarland R. A national perspective on prenatal testing for mitochondrial disease. Eur J Hum Genet 2014;22:1255-9.

19 Blakely EL, Yarham JW, Alston CL, Craig K, Poulton J, Brierley C, Park SM, Dean A, Xuereb JH, Anderson KN, Compston A, Allen C, Sharif S, Enevoldson P, Wilson M, Hammans SR, Turnbull DM, McFarland R, Taylor RW. Pathogenic mitochondria tRNA point mutations: nine novel mutations affirm their importance as a cause of mitochondrial disease. Hum Mutat 2013;34:1260-8.

20 Legros F, Chatzoglou E, Frachon P, Ogier De Baulny H, Laforet P, Jardel C, Godinot $C$, Lombes A. Functional characterization of novel mutations in the human cytochrome b gene. Eur J Hum Genet 2001;9:510-18.

21 Bruno C, Santorelli FM, Assereto S, Tonoli E, Tessa A, Traverso M, Scapolan S, Bado M, Tedeschi S, Minetti C. Progressive exercise intolerance associated with a new muscle-restricted nonsense mutation (G142X) in the mitochondrial cytochrome b gene. Muscle Nerve 2003;28:508-11.

22 Andreu AL, Hanna MG, Reichmann H, Bruno C, Penn AS, Tanji K, Pallotti F, Iwata S, Bonilla E, Lach B, Morgan-Hughes J, DiMauro S. Exercise intolerance due to mutations in the cytochrome $b$ gene of mitochondrial DNA. N Engl J Med 1999;341:1037-44.

23 Andreu AL, Checcarelli N, Iwata S, Shanske S, DiMauro S. A missense mutation in the mitochondrial cytochrome $b$ gene in a revisited case with histiocytoid cardiomyopathy. Pediatr Res 2000;48:311-14.

24 Zhadanov SI, Atamanov VV, Zhadanov NI, Schurr TG. De novo COX2 mutation in a LHON family of Caucasian origin: implication for the role of mtDNA polymorphism in human pathology. J Hum Genet 2006;51:161-70.

25 Smits $P$, Mattijssen $S$, Morava $E$, van den Brand $M$, van den Brandt $F$, Wijburg $F$, Pruijn G, Smeitink J, Nijtmans L, Rodenburg R, van den Heuvel L. Functional consequences of mitochondrial tRNA Trp and tRNA Arg mutations causing combined OXPHOS defects. Eur J Hum Genet 2010;18:324-9.

26 't Hart LM, Jansen JJ, Lemkes HH, de Knijff P, Maassen JA. Heteroplasmy levels of a mitochondrial gene mutation associated with diabetes mellitus decrease in leucocyte DNA upon aging. Hum Mutat 1996;7:193-7.

27 Howell N, Ghosh SS, Fahy E, Bindoff LA. Longitudinal analysis of the segregation of mtDNA mutations in heteroplasmic individuals. J Neurol Sci 2000;172:1-6.

28 Rahman S, Poulton J, Marchington D, Suomalainen A. Decrease of $3243 \mathrm{~A} \rightarrow \mathrm{G}$ mtDNA mutation from blood in MELAS syndrome: a longitudinal study. Am J Hum Genet 2001;68:238-40.

29 McDonnell MT, Schaefer AM, Blakely EL, McFarland R, Chinnery PF, Turnbull DM, Taylor RW. Noninvasive diagnosis of the $3243 \mathrm{~A}>\mathrm{G}$ mitochondrial DNA mutation using urinary epithelial cells. Eur J Hum Genet 2004;12:778-81.

30 O'Callaghan MM, Emperador S, Pineda M, Lopez-Gallardo E, Montero R, Yubero D, Jou C, Jimenez-Mallebrera C, Nascimento A, Ferrer I, Garcia-Cazorla A, Ruiz-Pesini E, Montoya J, Artuch R. Mutation loads in different tissues from six pathogenic mtDNA point mutations. Mitochondrion 2015;22:17-22.

31 Elson JL, Swalwell H, Blakely EL, McFarland R, Taylor RW, Turnbull DM. Pathogenic mitochondrial tRNA mutations-which mutations are inherited and why? Hum Mutat 2009;30:E984-92.

32 Li $M$, Rothwell $R$, Vermaat $M$, Wachsmuth $M$, Schroder $R$, Laros JF, van Oven $M$, de Bakker PI, Bovenberg JA, van Duijn CM, van Ommen GJ, Slagboom PE, Swertz MA, Wijmenga C, Kayser M, Boomsma DI, Zollner S, de Knijff P, Stoneking M. Transmission of human mtDNA heteroplasmy in the Genome of the Netherlands families: support for a variable-size bottleneck. Genome Res 2016;26:417-26.

33 Poulton J, Marchington DR. Segregation of mitochondrial DNA (mtDNA) in human oocytes and in animal models of mtDNA disease: clinical implications. Reproduction 2002;123:751-5.

34 Marchington D, Malik S, Banerjee A, Turner K, Samuels D, Macaulay V, Oakeshott $P$, Fratter C, Kennedy S, Poulton J. Information for genetic management of mtDNA disease: sampling pathogenic mtDNA mutants in the human germline and in placenta. J Med Genet 2010;47:257-61.

35 Mancuso M, Filosto M, Stevens JC, Patterson M, Shanske S, Krishna S, DiMauro S. Mitochondrial myopathy and complex III deficiency in a patient with a new stop-codon mutation (G339X) in the cytochrome b gene. J Neurol Sci 2003;209:61-3.

36 Keightley JA, Anitori R, Burton MD, Quan F, Buist NR, Kennaway NG. Mitochondrial encephalomyopathy and complex III deficiency associated with a stop-codon mutation in the cytochrome b gene. Am J Hum Genet 2000;67:1400-10.

37 Lebon S, Chol M, Benit P, Mugnier C, Chretien D, Giurgea I, Kern I, Girardin E, Hertz-Pannier L, de Lonlay P, Rotig A, Rustin P, Munnich A. Recurrent de novo mitochondrial DNA mutations in respiratory chain deficiency. J Med Genet 2003;40:896-9.
38 Steffann J, Gigarel N, Corcos J, Bonniere M, Encha-Razavi F, Sinico M, Prevot S, Dumez Y, Yamgnane A, Frydman R, Munnich A, Bonnefont JP. Stability of the m.8993T->G mtDNA mutation load during human embryofetal development has implications for the feasibility of prenatal diagnosis in NARP syndrome. J Med Genet 2007;44:664-9.

39 Shanske S, Coku J, Lu J, Ganesh J, Krishna S, Tanji K, Bonilla E, Naini AB, Hirano M, DiMauro S. The G13513A mutation in the ND5 gene of mitochondrial DNA as a common cause of MELAS or Leigh syndrome: evidence from 12 cases. Arch Neurol 2008;65:368-72.

40 Götz A, Isohanni P, Liljeström B, Rummukainen J, Nikolajev K, Herrgård E, Marjavaara S, Suomalainen A. Fatal neonatal lactic acidosis caused by a novel de novo mitochondrial G7453A tRNA-Serine ((UCN)) mutation. Pediatr Res 2012;72:90-4

41 Shanske S, Naini A, Chmait RH, Akman HO, Mansukhani M, Lu J, Hirano M, DiMauro $S$. Mutation in an mtDNA protein-coding gene: prenatal diagnosis aided by fetal muscle biopsy. J Child Neurol 2013;28:264-8.

42 White SL, Shanske S, McGill JJ, Mountain H, Geraghty MT, DiMauro S, Dahl HH, Thorburn DR. Mitochondrial DNA mutations at nucleotide 8993 show a lack of tissue- or age-related variation. J Inherit Metab Dis 1999;22:899-914.

43 Kirby DM, McFarland R, Ohtake A, Dunning C, Ryan MT, Wilson C, Ketteridge D, Turnbull DM, Thorburn DR, Taylor RW. Mutations of the mitochondrial ND1 gene as a cause of MELAS. J Med Genet 2004;41:784-9.

44 Mkaouar-Rebai E, Kammoun F, Chamkha I, Kammoun N, Hsairi I, Triki C, Fakhfakh F. A de novo mutation in the adenosine triphosphatase (ATPase) 8 gene in a patient with mitochondrial disorder. J Child Neurol 2010;25:770-5.

45 Baric I, Fumić K, Petković Ramadža D, Sperl W, Zimmermann FA, Muačevic-Katanec D, Mitrović Z, Pažanin L, Cvitanović Šojat L, Kekez T, Reiner Z, Mayr JA. Mitochondrial myopathy associated with a novel 5522G>A mutation in the mitochondrial tRNA(Trp) gene. Eur J Hum Genet 2013;21:871-5.

46 Anitori R, Manning K, Quan F, Weleber RG, Buist NR, Shoubridge EA, Kennaway NG. Contrasting phenotypes in three patients with novel mutations in mitochondrial tRNA genes. Mol Genet Metab 2005;84:176-88.

47 Biousse V, Brown MD, Newman NJ, Allen JC, Rosenfeld J, Meola G, Wallace DC De novo 14484 mitochondrial DNA mutation in monozygotic twins discordant for Leber's hereditary optic neuropathy. Neurology 1997;49:1136-8.

48 Steffann J, Monnot $S$, Bonnefont JP. mtDNA mutations variously impact mtDNA maintenance throughout the human embryofetal development. Clin Genet 2015;88:416-24.

49 Blok MJ, Spruijt L, de Coo IF, Schoonderwoerd K, Hendrickx A, Smeets HJ. Mutations in the ND5 subunit of complex I of the mitochondrial DNA are a frequent cause of oxidative phosphorylation disease. J Med Genet 2007;44:e74.

50 van den Bosch BJ, de Coo IF, Hendrickx AT, Busch HF, de Jong G, Scholte HR, Smeets HJ. Increased risk for cardiorespiratory failure associated with the A3302G mutation in the mitochondrial DNA encoded tRNALeu(UUR) gene. Neuromuscul Disord 2004;14:683-8.

51 Spruijt L, Smeets HJ, Hendrickx A, Bettink-Remeijer MW, Maat-Kievit A, Schoonderwoerd KC, Sluiter W, de Coo IF, Hintzen RQ. A MELAS-associated ND1 mutation causing leber hereditary optic neuropathy and spastic dystonia. Arch Neurol 2007;64:890-3.

52 Hanna MG, Nelson IP, Morgan-Hughes JA, Wood NW. MELAS: a new disease associated mitochondrial DNA mutation and evidence for further genetic heterogeneity. J Neurol Neurosurg Psychiatry 1998;65:512-17.

53 Darin N, Kollberg G, Moslemi AR, Tulinius M, Holme E, Gronlund MA, Andersson $S$, Oldfors A. Mitochondrial myopathy with exercise intolerance and retinal dystrophy in a sporadic patient with a G583A mutation in the mt tRNA(phe) gene. Neuromuscul Disord 2006;16:504-6.

54 Shoffner JM, Bialer MG, Pavlakis SG, Lott M, Kaufman A, Dixon J, Teichberg S, Wallace DC. Mitochondrial encephalomyopathy associated with a single nucleotide pair deletion in the mitochondrial tRNALeu(UUR) gene. Neurology 1995;45:286-92.

55 Ugalde C, Hinttala R, Timal S, Smeets R, Rodenburg RJ, Uusimaa J, van Heuvel LP, Nijtmans LG, Majamaa K, Smeitink JA. Mutated ND2 impairs mitochondrial complex I assembly and leads to Leigh syndrome. Mol Genet Metab 2007:90:10-14

56 Granadillo JL, Moss T, Lewis RA, Austin EG, Kelfer H, Wang J, Wong LJ, Scaglia F. Early onset and severe clinical course associated with the m.5540G $>$ A mutation in. Mol Genet Metab Rep 2014;1:61-5.

57 Moraes CT, Ciacci F, Bonilla E, Jansen C, Hirano M, Rao N, Lovelace RE, Rowland $L P$, Schon EA, DiMauro $S$. Two novel pathogenic mitochondrial DNA mutations affecting organelle number and protein synthesis. Is the tRNA(Leu(UUR)) gene an etiologic hot spot? J Clin Invest 1993;92:2906-15.

58 Valente L, Piga D, Lamantea E, Carrara F, Uziel G, Cudia P, Zani A, Farina L, Morandi L, Mora M, Spinazzola A, Zeviani M, Tiranti V. Identification of novel mutations in five patients with mitochondrial encephalomyopathy. Biochim Biophys Acta 2009;1787:491-501.

59 Kollberg G, Jansson M, Pérez-Bercoff A, Melberg A, Lindberg C, Holme E, Moslemi AR, Oldfors $A$. Low frequency of mtDNA point mutations in patients with PEO associated with POLG1 mutations. Eur J Hum Genet 2005;13:463-9. 
60 Gattermann N, Retzlaff S, Wang YL, Hofhaus G, Heinisch J, Aul C, Schneider W. Heteroplasmic point mutations of mitochondrial DNA affecting subunit I of cytochrome coxidase in two patients with acquired idiopathic sideroblastic anemia. Blood 1997:90:4961-72.

61 Seneca S, Goemans N, Van Coster R, Givron P, Reybrouck T, Sciot R, Meulemans A, Smet J, Van Hove JL. A mitochondrial tRNA aspartate mutation causing isolated mitochondrial myopathy. Am J Med Genet A 2005;137:170-5.

62 Rahman S, Taanman JW, Cooper JM, Nelson I, Hargreaves I, Meunier B, Hanna MG, Garcia JJ, Capaldi RA, Lake BD, Leonard JV, Schapira AH. A missense mutation of cytochrome oxidase subunit II causes defective assembly and myopathy. Am J Hum Genet 1999;65:1030-9.

63 McFarland R, Taylor RW, Chinnery PF, Howell N, Turnbull DM. A novel sporadic mutation in cytochrome coxidase subunit II as a cause of rhabdomyolysis. Neuromuscul Disord 2004;14:162-6

64 De Meirleir L, Seneca S, Lissens W, Schoentjes E, Desprechins B. Bilateral striatal necrosis with a novel point mutation in the mitochondrial ATPase 6 gene. Pediatr Neurol 1995;13:242-6.

65 Duno M, Wibrand F, Baggesen K, Rosenberg T, Kjaer N, Frederiksen AL. A novel mitochondrial mutation $\mathrm{m} .8989 \mathrm{G}>\mathrm{C}$ associated with neuropathy, ataxia, retinitis pigmentosa-the NARP syndrome. Gene 2013;515:372-5.

66 Santorelli FM, Shanske S, Macaya A, DeVivo DC, DiMauro S. The mutation at nt 8993 of mitochondrial DNA is a common cause of Leigh's syndrome. Ann Neurol 1993;34:827-34.

67 Pastores GM, Santorelli FM, Shanske S, Gelb BD, Fyfe B, Wolfe D, Willner JP. Leigh syndrome and hypertrophic cardiomyopathy in an infant with a mitochondrial DNA point mutation (T8993G). Am J Med Genet 1994;50: 265-71.

68 Uziel G, Moroni I, Lamantea E, Fratta GM, Ciceri E, Carrara F, Zeviani M. Mitochondrial disease associated with the T8993G mutation of the mitochondrial ATPase 6 gene: a clinical, biochemical, and molecular study in six families. J Neurol Neurosurg Psychiatry 1997;63:16-22.

69 Playan A, Solano-Palacios A, Gonzalez de la Rosa JB, Merino-Arribas JM, Andreu $A L$, Lopez-Perez M, Montoya J. [Leigh syndrome resulting from a de novo mitochondrial DNA mutation (T8993G)]. Rev Neurol 2002;34:1124-6.

70 Keightley JA, Hoffbuhr KC, Burton MD, Salas VM, Johnston WS, Penn AM, Buist NR, Kennaway NG. A microdeletion in cytochrome c oxidase (COX) subunit III associated with COX deficiency and recurrent myoglobinuria. Nat Genet 1996;12:410-16.

71 McFarland R, Kirby DM, Fowler KJ, Ohtake A, Ryan MT, Amor DJ, Fletcher JM, Dixon JW, Collins FA, Turnbull DM, Taylor RW, Thorburn DR. De novo mutations in the mitochondrial ND3 gene as a cause of infantile mitochondrial encephalopathy and complex I deficiency. Ann Neurol 2004;55:58-64.

72 Bannwarth S, Procaccio V, Rouzier C, Fragaki K, Poole J, Chabrol B, Desnuelle C, Pouget J, Azulay JP, Attarian S, Pellissier JF, Gargus JJ, Abdenur JE, Mozaffar T, Calvas $P$, Labauge P, Pages M, Wallace DC, Lambert JC, Paquis-Flucklinger V. Rapid identification of mitochondrial DNA (mtDNA) mutations in neuromuscular disorders by using surveyor strategy. Mitochondrion 2008;8:136-45.

73 Werner KG, Morel CF, Kirton A, Benseler SM, Shoffner JM, Addis JB, Robinson BH, Burrowes DM, Blaser SI, Epstein LG, Feigenbaum AS. Rolandic mitochondrial encephalomyelopathy and MT-ND3 mutations. Pediatr Neurol 2009;41:27-33.

74 Komaki H, Akanuma J, Iwata H, Takahashi T, Mashima Y, Nonaka I, Goto Y. A novel mtDNA C11777A mutation in Leigh syndrome. Mitochondrion 2003:2:293-304.

75 Zhadanov SI, Grechanina EY, Grechanina YB, Gusar VA, Fedoseeva NP, Lebon S, Munnich A, Schurr TG. Fatal manifestation of a de novo ND5 mutation: Insights into the pathogenetic mechanisms of mtDNA ND5 gene defects. Mitochondrion 2007;7:260-6.

76 Kirby DM, Kahler SG, Freckmann ML, Reddihough D, Thorburn DR. Leigh disease caused by the mitochondrial DNA G14459A mutation in unrelated families. Ann Neurol 2000;48:102-4

77 Valnot I, Kassis J, Chretien D, de Lonlay P, Parfait B, Munnich A, Kachaner J, Rustin P, Rötig A. A mitochondrial cytochrome b mutation but no mutations of nuclearly encoded subunits in ubiquinol cytochrome c reductase (complex III) deficiency. Hum Genet 1999;104:460-6.

78 Wibrand F, Ravn K, Schwartz M, Rosenberg T, Horn N, Vissing J. Multisystem disorder associated with a missense mutation in the mitochondrial cytochrome b gene. Ann Neurol 2001;50:540-3.

79 Lamantea E, Carrara F, Mariotti C, Morandi L, Tiranti V, Zeviani M. A novel nonsense mutation (Q352X) in the mitochondrial cytochrome $b$ gene associated with a combined deficiency of complexes I and III. Neuromuscul Disord 2002;12:49-52

80 Schaller A, Desetty R, Hahn D, Jackson CB, Nuoffer JM, Gallati S, Levinger L. Impairment of mitochondrial tRNAlle processing by a novel mutation associated with chronic progressive external ophthalmoplegia. Mitochondrion 2011;11:488-96.

81 Blakely EL, Swalwell H, Petty RK, McFarland R, Turnbull DM, Taylor RW. Sporadic myopathy and exercise intolerance associated with the mitochondrial $8328 \mathrm{G}>\mathrm{A}$ tRNALys mutation. J Neurol 2007;254:1283-5.
82 Jeppesen TD, Duno M, Risom L, Wibrand F, Rafiq J, Krag T, Jakobsen J, Andersen $H$, Vissing J. A novel de novo mutation of the mitochondrial tRNAlys gene mt.8340G $>$ a associated with pure myopathy. Neuromuscul Disord 2014;24:162-6.

83 Biancheri R, Rossi D, Cassandrini D, Rossi A, Bruno C, Santorelli FM. Cavitating leukoencephalopathy in a child carrying the mitochondrial A8344G mutation. AJNR Am J Neuroradiol 2010;31:E78-9.

84 Burrage LC, Tang S, Wang J, Donti TR, Walkiewicz M, Luchak JM, Chen LC, Schmitt ES, Niu Z, Erana R, Hunter JV, Graham BH, Wong LJ, Scaglia F. Mitochondrial myopathy, lactic acidosis, and sideroblastic anemia (MLASA) plus associated with a novel de novo mutation (m.8969G $>A$ ) in the mitochondrial encoded ATP6 gene. Mol Genet Metab 2014;113:207-12.

85 Seller A, Kennedy CR, Temple IK, Brown GK. Leigh syndrome resulting from de novo mutation at position 8993 of mitochondrial DNA. J Inherit Metab Dis 1997;20:102-3.

86 De Praeter C, Vanlander A, Vanhaesebrouck P, Smet J, Seneca S, De Sutter P, Van Coster R. Extremely high mutation load of the mitochondrial $8993 \mathrm{~T}>\mathrm{G}$ mutation in a newborn: implications for prognosis and family planning decisions. Eur J Pediatr 2015;174:267-70.

87 Leng Y, Liu Y, Fang X, Li Y, Yu L, Yuan Y, Wang Z. The mitochondrial DNA 10197 $\mathrm{G}>\mathrm{A}$ mutation causes MELAS/Leigh overlap syndrome presenting with acute auditory agnosia. Mitochondrial DNA 2015;26:208-12.

88 Nesbitt V, Morrison PJ, Crushell E, Donnelly DE, Alston CL, He L, McFarland R, Taylor RW. The clinical spectrum of the m.10191T>C mutation in complex I-deficient Leigh syndrome. Dev Med Child Neurol 2012;54:500-6.

89 Roos S, Darin N, Kollberg G, Andersson Grönlund M, Tulinius M, Holme E, Moslemi AR, Oldfors A. A novel mitochondrial tRNA Arg mutation resulting in an anticodon swap in a patient with mitochondrial encephalomyopathy. Eur J Hum Genet 2013;21:571-3.

90 Wong LJ, Yim D, Bai RK, Kwon H, Vacek MM, Zane J, Hoppel CL, Kerr DS. A novel mutation in the mitochondrial tRNA(Ser(AGY)) gene associated with mitochondrial myopathy, encephalopathy, and complex I deficiency. J Med Genet 2006:43:e46.

91 Karadimas CL, Salviati L, Sacconi S, Chronopoulou P, Shanske S, Bonilla E, De Vivo DC, DiMauro S. Mitochondrial myopathy and ophthalmoplegia in a sporadic patient with the G12315A mutation in mitochondrial DNA. Neuromuscul Disord 2002;12:865-8.

92 Alston CL, Morak M, Reid C, Hargreaves IP, Pope SA, Land JM, Heales SJ, Horvath $\mathrm{R}$, Mundy $\mathrm{H}$, Taylor RW. A novel mitochondrial MTND5 frameshift mutation causing isolated complex I deficiency, renal failure and myopathy. Neuromuscul Disord 2010:20:131-5

93 Slawek J, Kierdaszuk B, Tonska K, Kodron A, Schinwelski M, Sitek EJ, Bartnik E, Kaminska A, Kwiecinski H. Mitochondrial encephalopathy in a patient with a 13042G >A de novo mutation. J Clin Pathol 2012;65:1147-9.

94 Leshinsky-Silver E, Shuvalov R, Inbar S, Cohen S, Lev D, Lerman-Sagie T. Juvenile Leigh syndrome, optic atrophy, ataxia, dystonia, and epilepsy due to T14487C mutation in the mtDNA-ND6 gene: a mitochondrial syndrome presenting from birth to adolescence. J Child Neurol 2011;26:476-81.

95 Lax NZ, Gnanapavan S, Dowson SJ, Alston CL, He L, Polvikoski TM, Jaros E, O'Donovan DG, Yarham JW, Turnbull DM, Dean AF, Taylor RW. Early-onset cataracts, spastic paraparesis, and ataxia caused by a novel mitochondrial tRNAGlu (MT-TE) gene mutation causing severe complex I deficiency: a clinical, molecular, and neuropathologic study. J Neuropathol Exp Neurol 2013;72:164-75.

96 Mayr JA, Moslemi AR, Förster H, Kamper A, Idriceanu C, Muss W, Huemer M, Oldfors A, Sperl W. A novel sporadic mutation G14739A of the mitochondrial tRNA(Glu) in a girl with exercise intolerance. Neuromuscul Disord 2006:16:874-7.

97 De Coo IFM, Renier WO, Ruitenbeek W, Ter Laak HJ, Bakker M, Schägger H, Van Oost BA, Smeets HJ. A 4-base pair deletion in the mitochondrial cytochrome b gene associated with parkinsonism/MELAS overlap syndrome. Ann Neurol 1999:45:130-3

98 Emmanuele V, Sotiriou E, Rios PG, Ganesh J, Ichord R, Foley AR, Akman HO, Dimauro $S$. A novel mutation in the mitochondrial DNA cytochrome $b$ gene (MTCYB) in a patient with mitochondrial encephalomyopathy, lactic acidosis, and strokelike episodes syndrome. J Child Neurol 2013;28:236-42.

99 Fragaki K, Procaccio V, Bannwarth S, Serre V, O'Hearn S, Potluri P, Auge G, Casagrande F, Caruba C, Lambert JC, Paquis-Flucklinger V. A neonatal polyvisceral failure linked to a de novo homoplasmic mutation in the mitochondrially encoded cytochrome b gene. Mitochondrion 2009;9:346-52.

100 Bataillard M, Chatzoglou E, Rumbach L, Sternberg D, Tournade A, Laforet P, Jarde C, Maisonobe T, Lombes A. Atypical MELAS syndrome associated with a new mitochondrial tRNA glutamine point mutation. Neurology 2001;56:405-7.

101 Dey R, Tengan CH, Morita MP, Kiyomoto BH, Moraes CT. A novel myopathy-associated mitochondrial DNA mutation altering the conserved size of the tRNA(GIn) anticodon loop. Neuromuscul Disord 2000;10:488-92.

102 Vissing J, Salamon MB, Arlien-Søborg P, Nørby S, Manta P, DiMauro S, Schmalbruch $\mathrm{H}$. A new mitochondrial tRNA(Met) gene mutation in a patient with dystrophic muscle and exercise intolerance. Neurology 1998;50:1875-8. 
103 Pulkes T, Siddiqui A, Morgan-Hughes JA, Hanna MG. A novel mutation in the mitochondrial tRNA(TYr) gene associated with exercise intolerance. Neurology 2000;55:1210-12

104 Karadimas CL, Greenstein P, Sue CM, Joseph JT, Tanji K, Haller RG, Taivassalo T, Davidson MM, Shanske S, Bonilla E, DiMauro S. Recurrent myoglobinuria due to a nonsense mutation in the COX I gene of mitochondrial DNA. Neurology 2000;55:644-9.

105 Comi GP, Bordoni A, Salani S, Franceschina L, Sciacco M, Prelle A, Fortunato F, Zeviani M, Napoli L, Bresolin N, Moggio M, Ausenda CD, Taanman JW, Scarlato $\mathrm{G}$. Cytochrome c oxidase subunit I microdeletion in a patient with motor neuron disease. Ann Neurol 1998;43:110-16.

106 Bruno C, Martinuzzi A, Tang Y, Andreu AL, Pallotti F, Bonilla E, Shanske S, Fu J, Sue CM, Angelini C, DiMauro S, Manfredi G. A stop-codon mutation in the human mtDNA cytochrome $c$ oxidase I gene disrupts the functional structure of complex IV. Am J Hum Genet 1999;65:611-20.

107 Bidooki S, Jackson MJ, Johnson MA, Chrzanowska-Lightowlers ZM, Taylor RW, Venables G, Lightowlers RN, Turnbull DM, Bindoff LA. Sporadic mitochondrial myopathy due to a new mutation in the mitochondrial tRNASer(UCN) gene. Neuromuscul Disord 2004;14:417-20.

108 Campos Y, Garcia-Redondo A, Fernández-Moreno MA, Martínez-Pardo M, Goda G, Rubio JC, Martín MA, del Hoyo P, Cabello A, Bornstein B, Garesse R, Arenas J, Early-onset multisystem mitochondrial disorder caused by a nonsense mutation in the mitochondrial DNA cytochrome C oxidase II gene. Ann Neurol 2001;50:409-13.

109 Verma A, Piccoli DA, Bonilla E, Berry GT, DiMauro S, Moraes CT. A novel mitochondrial G8313A mutation associated with prominent initial gastrointestinal symptoms and progressive encephaloneuropathy. Pediatr Res 1997;42:448-54.

110 López-Gallardo E, Solano A, Herrero-Martín MD, Martínez-Romero I, Castaño-Pérez MD, Andreu AL, Herrera A, López-Pérez MJ, Ruiz-Pesini E, Montoya J. NARP syndrome in a patient harbouring an insertion in the MT-ATP6 gene that results in a truncated protein. J Med Genet 2009;46:64-7

111 Moslemi AR, Darin N, Tulinius M, Oldfors A, Holme E. Two new mutations in the MTATP6 gene associated with Leigh syndrome. Neuropediatrics 2005;36: 314-18.

112 Ruiter EM, Siers MH, van den Elzen C, van Engelen BG, Smeitink JA, Rodenburg $\mathrm{RJ}, \mathrm{Hol} F \mathrm{~F}$. The mitochondrial $13513 \mathrm{G}>\mathrm{A}$ mutation is most frequent in Leigh syndrome combined with reduced complex I activity, optic atrophy and/or Wolff-Parkinson-White. Eur J Hum Genet 2007;15:155-61.

113 Tarnopolsky M, Meaney B, Robinson B, Sheldon K, Boles RG. Severe infantile leigh syndrome associated with a rare mitochondrial ND6 mutation, m.14487T $>C$. Am J Med Genet A 2013:161A:2020-3.

114 Pereira C, Nogueira C, Barbot C, Tessa A, Soares C, Fattori F, Guimaraes A Santorelli FM, Vilarinho L. Identification of a new mtDNA mutation (14724G>A) associated with mitochondrial leukoencephalopathy. Biochem Biophys Res Commun 2007;354:937-41.

115 Schuelke M, Krude H, Finckh B, Mayatepek E, Janssen A, Schmelz M, Trefz F, Trijbels F, Smeitink J. Septo-optic dysplasia associated with a new mitochondrial cytochrome b mutation. Ann Neurol 2002;51:388-92.

116 Andreu AL, Bruno C, Dunne TC, Tanji K, Shanske S, Sue CM, Krishna S, Hadjigeorgiou GM, Shtilbans A, Bonilla E, DiMauro S. A nonsense mutation (G15059A) in the cytochrome b gene in a patient with exercise intolerance and myoglobinuria. Ann Neurol 1999;45:127-30.

117 Dumoulin R, Sagnol I, Ferlin T, Bozon D, Stepien G, Mousson B. A novel gly290asp mitochondrial cytochrome b mutation linked to a complex III deficiency in progressive exercise intolerance. Mol Cell Probes 1996;10:389-91.

118 Blakely EL, Mitchell AL, Fisher N, Meunier B, Nijtmans LG, Schaefer AM, Jackson MJ, Turnbull DM, Taylor RW. A mitochondrial cytochrome b mutation causing severe respiratory chain enzyme deficiency in humans and yeast. FEBS J 2005:272:3583-92.

119 Andreu AL, Bruno C, Shanske S, Shtilbans A, Hirano M, Krishna S, Hayward L, Systrom DS, Brown RH Jr, DiMauro S. Missense mutation in the mtDNA cytochrome b gene in a patient with myopathy. Neurology 1998;51:1444-7.

120 Nishino I, Seki A, Maegaki Y, Takeshita K, Horai S, Nonaka I, Goto Y. A novel mutation in the mitochondrial tRNA(Thr) gene associated with a mitochondrial encephalomyopathy. Biochem Biophys Res Commun 1996;225:180-5.

121 Ionasescu VV, Hart M, DiMauro S, Moraes CT. Clinical and morphologic features of a myopathy associated with a point mutation in the mitochondrial tRNA(Pro) gene. Neurology 1994:44:975-7.

122 Mancuso M, Filosto M, Mootha VK, Rocchi A, Pistolesi S, Murri L, DiMauro S, Siciliano G. A novel mitochondrial tRNAPhe mutation causes MERRF syndrome. Neurology 2004;62:2119-21.
123 Coulbault L, Deslandes B, Herlicoviez D, Read MH, Leporrier N, Schaeffer S, Mouadil A, Lombes A, Chapon F, Jauzac P, Allouche S. A novel mutation 3090 $\mathrm{G}>\mathrm{A}$ of the mitochondrial $16 \mathrm{~S}$ ribosomal RNA associated with myopathy. Biochem Biophys Res Commun 2007:362:601-5.

124 Campos Y, Martin MA, Lorenzo G, Aparicio M, Cabello A, Arenas J. Sporadic MERRF/MELAS overlap syndrome associated with the 3243 tRNA(Leu(UUR)) mutation of mitochondrial DNA. Muscle Nerve 1996;19:187-90.

125 Yamamoto M. Did de novo MELAS common mitochondrial DNA point mutation (mtDNA 3243, A $\rightarrow G$ transition) occur in the mother of a proband of a Japanese MELAS pedigree? I Neurol Sci 1996;135:81-4.

126 Ko CH, Lam CW, Tse PW, Kong CK, Chan AK, Wong LJ. De novo mutation in the mitochondrial tRNALeu(UUR) gene (A3243G) with rapid segregation resulting in MELAS in the offspring. J Paediatr Child Health 2001;37:87-90.

127 Maassen JA, Biberoglu S, 't Hart LM, Bakker $E$, de Knijff P. A case of a de novo A3243G mutation in mitochondrial DNA in a patient with diabetes and deafness. Arch Physiol Biochem 2002;110:186-8

128 Pallotti F, Binelli G, Fabbri R, Valentino ML, Vicenti R, Macciocca M, Cevoli S, Baruzzi A, DiMauro S, Carelli V. A wide range of 3243A>G/tRNALeu(UUR) (MELAS) mutation loads May segregate in offspring through the female germline bottleneck. PLOS ONE 2014;9:e96663.

129 Blakely EL, de Silva R, King A, Schwarzer V, Harrower T, Dawidek G, Turnbull DM, Taylor RW. LHON/MELAS overlap syndrome associated with a mitochondrial MTND1 gene mutation. Eur J Hum Genet 2005;13:623-7.

130 Taylor RW, Schaefer AM, McFarland R, Maddison P, Turnbull DM. A novel mitochondrial DNA tRNA(Ile) (A4267G) mutation in a sporadic patient with mitochondrial myopathy. Neuromuscul Disord 2002;12:659-64.

131 Houshmand M, Lindberg C, Moslemi AR, Oldfors A, Holme E. A novel heteroplasmic point mutation in the mitochondrial tRNA(Lys) gene in a sporadic case of mitochondrial encephalomyopathy: de novo mutation and no transmission to the offspring. Hum Mutat 1999;13:203-9.

132 Brinckmann A, Rüther K, Williamson K, Lorenz B, Lucke B, Nürnberg P, Trijbels F, Janssen A, Schuelke M. De novo double mutation in PAX6 and mtDNA tRNA(Lys) associated with atypical aniridia and mitochondrial disease. J Mol Med (Berl) 2007:85:163-8.

133 Tulinius $\mathrm{MH}$, Houshmand $\mathrm{M}$, Larsson N-G, Holme $\mathrm{E}$, Oldfors A, Holmberg $\mathrm{E}$ Wahlström J. De novo mutation in the mitochondrial ATP synthase subunit 6 gene (T8993G) with rapid segregation resulting in Leigh syndrome in the offspring. Hum Genet 1995;96:290-4.

134 de Coo IF, Smeets HJ, Gabreels FJ, Arts N, van Oost BA. Isolated case of mental retardation and ataxia due to a de novo mitochondrial T8993G mutation. Am J Hum Genet 1996;58:636-8.

135 Degoul F, Francois D, Diry M, Ponsot G, Desguerre I, Héron B, Marsac C, Moutard ML. A near homoplasmic T8993G mtDNA mutation in a patient with atypic Leigh syndrome not present in the mother's tissues. J Inherit Metab Dis 1997;20:49-53.

136 Santorelli FM, Tanji K, Shanske S, DiMauro S. Heterogeneous clinical presentation of the mtDNA NARP/T8993G mutation. Neurology 1997;49:270-3.

137 Takahashi S, Makita Y, Oki J, Miyamoto A, Yanagawa J, Naito E, Goto Y, Okuno A. De novo mtDNA nt $8993(T \rightarrow G)$ mutation resulting in Leigh syndrome. Am J Hum Genet 1998:62:717-19.

138 Horvath R, Scharfe C, Hoeltzenbein M, Do BH, Schroder C, Warzok R, Vogelgesang S, Lochmuller H, Muller-Hocker J, Gerbitz KD, Oefner PJ, Jaksch M. Childhood onset mitochondrial myopathy and lactic acidosis caused by a stop mutation in the mitochondrial cytochrome c oxidase III gene. J Med Genet 2002;39:812-16.

139 Tiranti V, Corona P, Greco M, Taanman JW, Carrara F, Lamantea E, Nijtmans L, Uziel G, Zeviani M. A novel frameshift mutation of the mtDNA COIII gene leads to impaired assembly of cytochrome c oxidase in a patient affected by Leigh-like syndrome. Hum Mol Genet 2000;9:2733-42.

140 Pancrudo J, Shanske S, Coku J, Lu J, Mardach R, Akman O, Krishna S, Bonilla E, DiMauro $S$. Mitochondrial myopathy associated with a novel mutation in mtDNA. Neuromuscul Disord 2007;17:651-4.

141 Taylor RW, Schaefer AM, McDonnell MT, Petty RK, Thomas AM, Blakely EL, Hayes CM, McFarland R, Turnbull DM. Catastrophic presentation of mitochondrial disease due to a mutation in the tRNA(His) gene. Neurology 2004;62:1420-3.

142 Melone MA, Tessa A, Petrini S, Lus G, Sampaolo S, di Fede G, Santorelli FM, Cotrufo R. Revelation of a new mitochondrial DNA mutation (G12147A) in a MELAS/MERFF phenotype. Arch Neurol 2004;61:269-72.

143 Blakely EL, Trip SA, Swalwell H, He L, Wren DR, Rich P, Turnbull DM, Omer SE, Taylor RW. A new mitochondrial transfer RNAPro gene mutation associated with myoclonic epilepsy with ragged-red fibers and other neurological features. Arch Neurol 2009;66:399-402. 